\title{
SER NO MUNDO, MUNDO VIVIDO E CORPO PRÓPRIO SEGUNDO MERLEAU-PONTY
}

\section{Denis de Souza AZEVEDO ${ }^{1}$ e Iraquitan de Oliveira CAMINHA ${ }^{2}$}

${ }^{1}$ Mestrando do Programa de Pós-Graduação em Filosofia/UFPB; E-mail: souza.denisde@gmail.com

${ }^{2}$ Programa de Pós-Graduação em Filosofia/UFPB; E-mail: caminhairaquitan@gmail.com

Artigo submetido em fevereiro/2015 e aceito em abril/2015

DOI: $10.15628 /$ dialektike.2015.3009

\section{RESUMO}

Abordaremos, neste artigo, a conexão entre ser no mundo e mundo vivido, tendo como foco de nossa investigação o sentido de corpo próprio para MerleauPonty. Em outros termos, o que iremos expor aqui é o modo como o sujeito está situado no mundo pelo corpo e pelas suas ações intencionais. Destacaremos a noção de perspectiva como experiência fundante da percepção do corpo que "vê" e "se vê" ao mesmo tempo. Nesse sentido, o corpo, por sua vez, não pode ser reduzido a um mero objeto de estudo a ciência positiva. Tal corpo é, ao mesmo tempo, tocante e tocado, que sente e é sentido. Ele é, neste emaranhado de passividades e atitudes, uma mescla de afetar e ser afetado. Pois, de um só golpe, nosso corpo é coisa e sujeito. Sendo assim, a nossa visão perspectivista sobre algo é de tal modo que conseguimos ultrapassá-lo por meio dos movimentos intencionais que nos possibilita considerar o objeto a partir de certos ângulos e com infinitas possibilidades de aparições. Por fim, o foco de nosso trabalho é a Fenomenologia da percepção, uma vez que, nesta obra, Merleau-Ponty trata a percepção como acesso ao mundo.

PALAVRAS-CHAVE: Ser no mundo; Mundo Vivido; Corpo próprio; Merleau-Ponty.

\section{BEING-IN-THE-WORLD, LIVED WORLD AND OWN BODY ACCORDING MERLEAU- PONTY}

\section{ABSTRACT}

We will discuss in this article, the connection between being in the world and lived world, focusing our research the meaning of his own body to Merleau-Ponty. In other words, what we will expose here is the way the subject is in the world through the body and their intentional actions. We will highlight the notion of perspective as foundational experience of body awareness that "see" and "see itself" the same time. In this sense, the body, in turn, can not be reduced to a mere object of study the positive science. This body is at the same time touching
\end{abstract}

and touched, that feels and is felt. It is in this tangle of passivity and attitudes, a mixture of affecting and being affected. For, at a stroke, our body is a thing and subject. Thus, our perspectival view on something is so that we overcame it through intentional movements that enables us to consider the object from certain angles and endless possibilities of appearances. Finally, the focus of our work is the Phenomenology of perception, since, in this work, Merleau-Ponty treats perception as access to the world.

KEYWORDS: Being in the world; Lived world; Own body; Merleau-Ponty. 


\title{
1 INTRODUÇÃO: O CORPO OBJETIVO E SUAS LIMITAÇÕES FILOSÓFICAS
}

A objetividade corpórea é evidente quando falamos do outro e até de nós mesmos enquanto estamos situados na factualidade do mundo. Este corpo que é tocado por mim, por outrem ou que é chocado com qualquer outro objeto é um conglomerado material que não escapa às constantes determinações físicas. Nesta perspectiva objetivista, ele é uma coisa como outra qualquer que está aí, no seio do mundo.

Para termos uma noção de que nosso corpo objetivo, tratado como mero objeto físico, reduz a existência do ser no mundo a uma existência empobrecida e limitada, Merleau-Ponty lança mão dos argumentos da anosognose - quando uma pessoa deficiente não é consciente de sua própria deficiência por razões de natureza neurológica - e do membro fantasma. Um paciente que, por exemplo, perdeu seu braço ainda o sente de uma forma objetivante, ou seja, o braço fantasma "emite" sensações que se concretizam na corporeidade do paciente como se o membro ali estivesse presente. Esta sensação não pode ser explicada exclusivamente nem por um viés fisiológico nem psicológico. Um tratamento fisiológico ou psicológico atribuiria ao problema ainda uma abordagem objetivo-científica, pois, se assim fosse, não sairíamos do campo da objetividade que engloba as reações interoceptivas e exteroceptivas. Em outros termos, estas reações seriam os estímulos captados pelo cérebro a partir de uma "enformação" das reações orgânicas - no caso da interoceptividade - e de uma "enformação" dos estímulos perceptivos gerais advindos da superfície do corpo - no caso da exteroceptividade. Dessa forma, se tratarmos os problemas da anosognose e do membro fantasma no arcabouço da fisiologia e da psicologia não teremos a compreensão da noção de ser no mundo tal como a fenomenologia se propõe a mostrar. Isto é, estes problemas, assim estudados, continuariam no campo do corpo objetivo, sem considerá-lo no contexto do mundo vivido. Assim,

\begin{abstract}
Uma explicação fisiológica interpretaria a anosognose e o membro fantasma como a simples supressão ou a simples persistência das estimulações interoceptivas. Nessa hipótese, a anosognose é a ausência de um fragmento da representação do corpo que deveria ser dada, já que o membro correspondente está ali; o membro fantasma é a presença de uma parte da representação do corpo que não deveria ser dada, já que o membro correspondente não está ali. Se agora damos uma explicação psicológica dos fenômenos, o membro fantasma torna-se uma recordação, um juízo positivo ou uma percepção, a anosognose um esquecimento, um juízo negativo ou uma não-percepção. No primeiro caso, o membro fantasma é a presença efetiva de uma representação. No segundo caso, o membro fantasma é a representação de uma ausência efetiva. Nos dois casos nós não saímos das categorias do mundo objetivo, em que não há meio-termo entre a presença e a ausência. (MERLEAU-PONTY, 2011, p. 119-120).
\end{abstract}

Isso nos mostra que ambas as explicações reduzem o ser no mundo a um mero corpo que é tratado como uma soma de processos mensuráveis pela ciência. Tal tratamento suprime a condição do ser no mundo no sentido pré-reflexivo, que significa sua existência no mundo anterior a qualquer juízo que possamos fazer dele.

O corpo objetivo, assim concebido, é parte apenas da concretude mundana enquanto estrutura mecânica. É objeto como outro qualquer apenas no modo em que se tornar coisa mundana, um objeto para a ciência. A consciência corpórea é, dentre outros aspectos, também uma forma de o ser no mundo posicionar-se enquanto coisa extensa. No entanto, esta consciência de um corpo objetivo é acompanhada, irremediavelmente, de uma consciência inerente ao próprio 
corpo, ou seja, do corpo que sente e é sentido ao mesmo tempo. No que diz respeito à consciência corporal, que ao mesmo tempo é tocante e tocado, Jaspers (1973, p. 109) nos mostra o seguinte:

Como da existência, tenho consciência do corpo mas, ao mesmo tempo, posso vê-lo com os olhos e tocá-lo com as mãos. O corpo é a única parte do mundo que se sente e - na superfície se percebe por dentro. É, para mim, um objeto e eu sou este mesmo corpo. Sem dúvida, como me sinto como corpo e como me percebo como objeto, são duas coisas diversas, mas indissoluvelmente ligadas. As sensações corpóreas, de que se constituem para mim um objeto conhecido, e as sensações que permanecem sentimentos do estado de um corpo, são as mesmas sensações e inseparáveis, embora se possa distingui-las.

O corpo, ora objetivo ora sujeito é a expressão da ambivalência de um ser que se recusa, a todo instante, ser apenas empírico ou apenas intelectivo. Dessa forma, uma abordagem filosófica a respeito do corpo objetivo torna-se impossível pelo fato de a res extensa não atribuir ao ser no mundo toda a carga existencial que o é própria. É preciso que haja, atrelada a esta coisa, uma dimensão subjetiva que interaja com o mundo e vá em direção a este. Só na unidade do objetivo com o subjetivo podemos pôr o ser no mundo e o seu mundo vivido correlacionados um ao outro.

A existência humana é marcada, ambiguamente, pela factualidade do corpo e pela dimensão subjetiva que este mesmo corpo a comporta. É preciso frisar, para dar conta da problemática existencial, que o nosso corpo não apenas é regido pelas leis que "controlam" a natureza. Além, evidentemente, de estar submetido às constantes físicas, ele também está submetido, por assim dizer, às decisões voluntárias de um eu que, intencionalmente, produz ações espontâneas. Portanto, "a experiência de nosso corpo, tal como ele é vivido e usado, desvenda uma dimensão que a ele escapa." (BARBARAS, 2011, p. 13). Isso mostra o quão limitado é a leitura do corpo objetivo, tomado apenas como um aglomerado de matéria. Assim sendo, "fenomenologicamente, a vivência do próprio corpo está estreitamente ligada à vivência do sentimento, dos impulsos, da consciência do eu." (JASPERS, 1973, p. 111). Não dá para separar corpo objeto de corpo sujeito. Embora possamos distingui-los, não podemos tratá-los em separado quando queremos examinar a existência humana no mundo, considerando a vida subjetiva que advém do próprio corpo que se dirige intencionalmente para as coisas.

A impossibilidade de tratar o ser no mundo exclusivamente a partir do corpo objeto dar-seá em detrimento de que aquele é uma unidade, por assim dizer, de um "eu sou" enquanto "eu posso". Em outros termos, um corpo objetificado está ou é no mundo, inevitavelmente. Contudo, tal corpo é um corpo que se locomove livremente no espaço e que está constantemente voltado para o mundo em que está situado. Dessa forma, é o corpo também animado pelas ações do "eu posso", ou seja, do corpo que, por meio da intencionalidade,realiza atos livros e escreve uma história de vida. Assim, "[o] corpo é o veículo do ser no mundo, e ter um corpo é, para um ser vivo, juntar-se a um meio definido, confundir-se com certos projetos e empenhar-se continuamente neles." (MERLEAU-PONTY, 2011, p. 122).

Portanto, atrelado ao corpo objeto que também somos, é preciso considerar o corpo sujeito que está arraigado na carcaça corpórea material e que a permite ser esta corporeidade dinâmica, que ora está aqui e ora está acolá por meio de movimentos intencionais e livres.

\section{O CORPO SUJEITO}

A existência é marcada pela ambiguidade entre o corpo objeto ou fisiológico e o corpo próprio que não somente está no mundo, mas habita o mundo, fazendo dele um mundo vivido. A 
explicação para a anosognose e o membro fantasma, na fenomenologia merleau-pontyana, baseia-se na conjuntura desta ambiguidade na qual temos frisado. Não há uma explicação de cunho apenas fisiológico e nem também apenas de cunho psicológico. A explicação nos ditames do ser no mundo dar-se-á por meio do tratamento da sua existência originária.

A vivência do ser no mundo é tal que sua liberdade também é condicionada, em certos aspectos, pela submissão às leis naturais. No entanto, a principal característica daquele é estar, constantemente, em situações que exigem suas tomadas de decisões, seus atos intencionais. No que concerne ao membro fantasma e à anosognose, portanto,

Esse fenômeno, que as explicações fisiológicas e psicológicas igualmente desfiguram, é compreensível ao contrário na perspectiva do ser no mundo. Aquilo que em nós recusa a mutilação e a deficiência é um Eu engajado em um certo mundo físico e inter-humano, que continua a estender-se para seu mundo a despeito de deficiências ou de amputações, e que, nessa medida, não as reconhece de jure. (MERLEAU-PONTY, 2011, p. 121).

Tratar o ser no mundo não como coisa, mas como uma junção de objeto e sujeito, e, além disso, uma junção que não é posta no mundo, mas, ao contrário é no mundo, torna compreensível a explicação da anosognose e do membro fantasma fenomenologicamente.

O membro fantasma é sentido pelo corpo por meio de uma situação de inerência do ser no mundo ao seu mundo vivido. Um corpo que é no mundo tem suas aberturas a tal mundo de uma forma que se torna impossível separá-los. Dessa forma, quando um membro é amputado e o paciente continua a senti-lo, a explicação fenomenológica a este evento perpassa pela concepção de vivência imanente ao mundo situado por este corpo, um mundo que ainda é o único campo de ação para tal paciente que permanece aberto às suas intenções de outrora. Em outras palavras, "[t]er um braço fantasma é permanecer aberto a todas as ações das quais apenas o braço é capaz, é conservar o campo prático que se tinha antes da mutilação." (MERLEAU-PONTY, 2011, p. 121122). Vemos, com isso, que sentir o braço, por exemplo, mesmo após sua mutilação é continuar nesta forma originária de existência que não nos permite ser separáveis do nosso mundo vivido. Isto é, a totalidade corpórea do ser no mundo é tal que a consciência que se tem dela é uma consciência plena, ou seja, que está arraigada, por assim dizer, na própria completude do ser no que se refere à sua corporeidade.

A consciência do corpo, segundo Jaspers (1973, p. 110),

esclarecer-se-á fenomenologicamente por meio da apresentação de nossa vivência total do corpo. [...] Temos uma sensação específica de nosso ser corpóreo nos movimentos da locomoção, na impressão que se espera de nossa corporeidade sobre os outros, na constituição de robustez e debilidade, de alteração de postura. Tudo isso são momentos de nossa pessoa vital. (grifos do autor)

Assim, a totalidade corporal própria de cada ser torna-se uma unidade indiscernível e, por isso, a dificuldade de "entender" sua amputação ou sua deficiência. Como mencionado na última citação de Merleau-Ponty, o campo prático do amputado permanece aberto quando o relacionamos com esta totalidade corporal inerente, isto é, o ser no mundo resiste em "aceitar" sua amputação quando, em sua vivência originária, sua unidade corpórea é a única possibilidade de explorar o mundo situado. Dessa forma, a recusa da deficiência é a maneira que o ser no mundo tem de continuar vivendo como abertura que Ihe é devida. 
Para tentar ilustrar esta dicotomia entre estar amputado ou deficiente e não os reconhecer, Merleau-Ponty (2011, p. 122-123) lança mão de uma diferenciação básica entre corpo habitual e corpo atual:

A ambiguidade do ser se reduz ao fato de que nosso corpo comporta como que duas camadas distintas, a do corpo habitual e a do corpo atual. Na primeira, figuram os gestos de manuseio que desapareceram da segunda, e a questão de saber como posso sentirme provido de um membro que de fato não tenho mais redunda em saber como o corpo habitual pode aparecer como fiador do corpo atual.

Esta duplicidade corporal é o fator determinante e originário que o ser no mundo "encontra" para continuar a ser possível de executar as mesmas atividades que praticava anteriormente à sua deformidade. Este "encontra" não pode ser confundido com um "encontrar" nos ditames da intencionalidade, ou seja, o ser no mundo não tem a consciência de querer se sentir capaz, mesmo sem o ser. Ao contrário, é uma situação na qual o ser no mundo está totalmente imerso e que, assim, sem se dar conta, permanece voltado ao mundo de forma que ignora sua limitação.

A explicação merleau-pontyana para esta "inconsciência" da amputação, no caso do membro fantasma, é baseada no recalque nos moldes da psicanálise. Em outras palavras, a negação do membro amputado ou até a recusa da deficiência é a não superação do corpo frente à sua nova maneira de vivenciar seu mundo vivido. Isto é, a transição efetiva de um "corpo são" para um "corpo privado" de certas atividades que não podem ser realizadas. Para o ser inconscientemente limitado, a limitação passa a ser não uma limitação real, mas apenas possível, e, com isso, o ser no mundo não reconhece tal privação como sua de fato. O recalque, de que Merleau-Ponty (2011, p. 123) quer falar,

consiste em que o sujeito se empenha em uma certa via - relação amorosa, carreira, obra-, encontra uma barreira nessa via e, não tendo força nem para transpor o obstáculo nem para renunciar ao empreendimento, permanece bloqueado nessa tentativa e emprega indefinidamente suas forças em renová-la em espírito. O tempo que passa não leva consigo os objetos impossíveis, não se fecha sobre a experiência traumática, o sujeito permanece sempre aberto ao mesmo futuro impossível, senão em seus pensamentos explícitos, pelo menos em seu ser efetivo. (Grifos nossos).

Assim, vemos que o ser no mundo, obcecado por sua abertura ao mundo que lhe é originária, não ultrapassa esta "cegueira" e sua existência passa a ser um possível quebrantado por uma realidade distinta, e, com isso, este possível passa a ser, na verdade, impossível. Em outros termos, a finalidade possível à qual o corpo deficiente almeja não é alcançável justamente por sua limitação. É um possível rarefeito, uma vez que é concebido apenas por um ser obcecado. Em suma, a realidade corpórea deste ser deficiente torna aquela sua suposta possibilidade um real impossível, tendo em vista que não é executável dentro da sua margem de capacidade atual.

A sensação do corpo habitual, ao qual se reportou Merleau-Ponty, permanece aparente ao paciente amputado, no caso do membro fantasma. Nesta conta, Jaspers (1973, p. 111) também discorre:

É assombroso como se sentem os membros amputados. Trata-se da ação do esquema corpóreo habitual que permanece após a amputação. É que o esquema corpóreo não é apenas um saber flutuante, relativo ao próprio corpo e sim um 
modo de apreender, profundamente implantado durante toda a vida, no qual as diversas sensações corpóreas constituem um todo.

Com isso, o recalque vem tentar explicar, como já mencionamos, esta impossibilidade de ultrapassamento do limite corporal atual. O sujeito limitado encontra-se ainda preso ao seu tempo pessoal, no qual seu corpo completo está intacto. Sendo assim, seu corpo habitual insiste em manter-se "presente" na vivência atual do ser no mundo. Pois, o "membro fantasma [...] é a permanência de uma certa equivalência entre corpo e mundo, de uma certa montagem da experiência (a contar como membro amputado) que se impõe sobre a consciência e vontade do amputado." (FERRAZ, 2006, p. 89). Esta imposição que o membro fantasma vem a cometer no deficiente é a recusa do ser originário em mudar-se, em adaptar-se a um novo modo existencial, e, assim, "o campo de ações do corpo habitual se sobrepõe àquele do corpo atual, reduzido com a amputação." (FERRAZ, 2006, p. 89). É esta sobreposição de um corpo, ou de um modelo de corpo, de outrora que o recalque expõe.

O indivíduo amputado não tem recordação da sua conjuntura corpórea passada e, com isso, tenta permanecer o mesmo. Ao contrário, esta prisão a um corpo que não tem mais é de uma forma imperceptível e não intencional do próprio sujeito.

Todo recalque é a passagem da existência em primeira pessoa a um tipo de escolástica dessa existência, que vive para uma experiência antiga ou antes para a recordação de tê-la tido, depois para a recordação de ter tido essa recordação e assim por diante, a ponto de que finalmente ela só retenha sua forma típica. (MERLEAU-PONTY, 2011, p. 124).

Vemos que esta recordação à qual o nosso autor se reportou é uma recordação que passa a ser involuntária do próprio ser no mundo. Isto é, de tanto ter estado aberto, de forma intrínseca, a seu mundo vivido num conjunto corporal habitual, o ser no mundo, mesmo privado de determinado membro, continua numa investida fracassada "fomentada" pela estrutura "acostumada" de um ser fisicamente completo.

Esta insistente trama de deixar o ser no mundo sentindo um corpo que não é mais seu é entendido a partir de um mundo ao qual primeiro é preciso habitar: o nosso mundo vivido. Em outras palavras, o ser originário que somos é tal que não habita - ou não é - em seu mundo de forma que sua vivência seja separada deste e que se perceba parte distinta. O ser no mundo é parte inerente de seu mundo circundante; é o meio pelo qual inúmeros acontecimentos mundanos o perpassam e, dessa forma, torna-o uma parte integrante de toda conjuntura de um mundo concreto. A dificuldade de vencer a amputação se dá neste entrelaçamento próprio de cada ser no mundo, pois a inconsciência, por assim dizer, da limitação é obscurecida pela existência concomitante das adversidades mundanas e subjetivas, que não permitem conscientizar uma parte do corpo em separado. Para nos mostrar esta existência pré-pessoal, ou seja, uma existência pré-consciente - que não permite ser consciente para depois existir -, Merleau-Ponty (2011, p. 125) afirma:

Assim como se fala de um recalque no sentido estrito quando, através do tempo, mantenho um dos mundos momentâneos pelos quais passei e faço dele a forma de toda a minha vida - da mesma maneira pode-se dizer que meu organismo, como adesão pré-pessoal à forma geral do mundo, como existência anônima e geral, desempenha, abaixo de minha vida pessoal, o papel de um complexo inato. 
Ele não existe como uma coisa inerte, mas esboça, ele também, o movimento da existência. Pode mesmo ocorrer que, no perigo, minha situação humana apague minha situação biológica, que meu corpo se lance sem reservas à ação. Mas esses momentos só podem ser momentos e a maior parte do tempo a existência pessoal recalca o organismo, sem poder nem ir adiante nem renunciar a si mesma - nem reduzi-lo a ela nem reduzir-se a ele. (Grifos do autor).

Como quer Merleau-Ponty, a existência pessoal, na maior parte das vezes, ofusca o corpo natural, biológico. Sendo assim, o ser no mundo existe de forma que suas funções biológicas passam a ser meras funções mecânicas que, imperceptivelmente, mantêm-no no seio do mundo vivido. Como o membro que foi amputado e deu lugar à sua "sombra" - por meio de uma sensação indistinta da vida habitual do indivíduo - fazia parte desta imperceptibilidade mecânicocorpórea, o ser no mundo resiste em aceitar seu novo arranjo físico e sua existência baseia-se, como de costume, no conjunto nato de seu corpo. Esta resistência em aceitar, como já frisamos, não é uma resistência intencional, e, sim, uma resistência recalcada, nos termos da psicanálise.

A partir destas concepções de corpo objeto e corpo sujeito, nesta mescla paradoxal entre um e outro, é que podemos tratar o corpo próprio, ou seja, o corpo vivido, como quer MerleauPonty na Fenomenologia da percepção, a saber: o corpo correlato à amplitude do "eu posso". Este, por sua vez, é a junção, podemos dizer assim, das duas dimensões - objetiva e subjetiva - que o ser no mundo traz em sua vivência originária e habitual.

O corpo vivido, na concepção merleau-pontyana, vai de encontro às teorias da consciência representacionista do corpo. Em outras palavras,

Os defensores da abordagem representacionalista afirmam que, a fim de explicar a consciência corporal, é preciso apelar para representações mentais do corpo. Em uma definição mínima da noção de representação, uma representação do corpo é uma estrutura interna que tem a função de controlar o estado do corpo e codificá-lo, que pode deturpar o corpo e que pode ser dissociada a partir do corpo. ${ }^{1}$ (DE VIGNEMONT, 2011, tradução nossa).

Assim, a noção de corpo próprio - ou corpo vivido - vem superar esta abordagem que suprime o tratamento do ser no mundo dentro da fenomenologia. O representacionismo corporal, por meio da consciência do próprio corpo, não permite considerar o corpo no seu mundo vivido, uma vez que agir através da consciência de meu corpo torna-me um ser quase que autômato. Isso porque, ao ter consciência de uma certa forma corporal, passo a agir conforme ou sou possibilitado por aquele modelo.

No que se refere ao corpo próprio, os movimentos intencionais nada têm a ver, pelo menos diretamente, com a consciência que se tem do corpo. O corpo vivido, e, naturalmente, sua existência no mundo circundante, é da ordem do estar engajado numa concretude da qual não se pode distanciar-se e que seu hábito vivencial é de tal forma que seus movimentos mais adversos já estão impregnados por sua maneira "mágica" de ser, de fazer, de querer, de intencionar e de poder se antecipar até mesmo a uma certa ação futura. Isto é, o ser no mundo é,

\footnotetext{
1"Proponents of the representationalist approach claim that in order to account for bodily awareness one needs to appeal to mental representations of the body. On a minimal definition of the notion of representation, a body representation is an internal structure that has the function to track the state of the body and encode it, that can misrepresent the body and that can be decoupled from the body."
} 
irremediavelmente, abarcado por sua existência inerente e originária no seu mundo. Assim, "[o] corpo vivido é entendido em termos de seu engajamento prático com o mundo." ${ }^{2}$ (DE VIGNEMONT, 2011, tradução nossa).

Quando falamos em "originário" queremos dizer que, no caso do ser no mundo, sua abertura ao mundo, às coisas e ao outro se dá através de sua posição pré-reflexiva, ou seja, na posição que ainda não tem uma consciência de tudo o que faz ou poderá fazer. Esta intencionalidade originária, portanto, entendida nestes termos, é a forma mais básica e primária que podemos aludir a qualquer ser que aja, que tenha consigo esta possibilidade de ser no mundo e manifestar em direção a ele como forma de vida autêntica e pré-consciente.

A correlação entre corpo próprio e mundo é de comunicação, isto é, o corpo vivido não pertence exclusivamente à dimensão de objeto colocado ou localizado no espaço. A relação que tenho com meu mundo vivido é uma relação de inerência, de descoberta e pela qual o mundo existe para mim e eu existo nele, efetivamente. Pois,

a permanência do corpo próprio, se a psicologia clássica a tivesse analisado, podia conduzi-la ao corpo não mais como objeto do mundo, mas como meio de nossa comunicação com ele, ao mundo não mais como soma de objetos determinados, mas como horizonte latente de nossa experiência, presente sem cessar, ele também, antes de todo pensamento determinante. (MERLEAU-PONTY, 2011, p. 136-137).

É neste itinerário, portanto, que Merleau-Ponty lança mão da noção de hábito e esquema corporal para dar conta dos problemas da deficiência e membro fantasma. Se o corpo próprio não pode ser entendido como objeto entre todos os outros, então sua reação existencial aos estímulos mundanos e aos estímulos de sua própria vivência concreta é a forma mais autêntica e habitual que ele encontra para enfrentá-los. Esta reação não pode ser confundida por um ato produzido pelo intelecto, de forma premeditada. Quando falamos de esquema corporal, de corpo habitual, falamos do modo originário de o ser no mundo se portar em seu ambiente vivido, em seu contexto existencial do qual é impossível se desvencilhar. Assim, a capacidade de o indivíduo responder ao mundo, primariamente, com sua existência efetiva é tal que não é produto da ordem do intelecto, como se fosse uma máquina programada e que respondesse por meio de uma programação cognitiva de antemão.

Mas esse poder, por sua vez, não é oriundo do entendimento, fruto de uma análise intelectual. O hábito implica a apreensão de significações pelo corpo: ele compreende a meta a ser realizada e espontaneamente articula os poderes perceptivo-motores para sua realização. Essa compreensão corporal difere daquela intelectual, em que subsume "um dado sensível sob uma ideia". (FERRAZ, 2006, p. 93, grifos do autor).

Vale salientar que, justamente por não ser uma ação deliberada pelo entendimento, é que os grifos feitos pelo autor são evidentes, ou seja, o hábito corporal, imerso no mundo, se junta a este como sendo uma extensão dele, sem ser parte separada. Dessa forma, "[o] espaço corpóreo é um espaço de ações dotadas de significados existenciais, de formas de existência em direção aos objetos. Por isso, o esquema do corpo consiste numa função sensório-motora, em vez de uma representação sensório-motora." ${ }^{3}$ (DE VIGNEMONT, 2011, grifo do autor, tradução nossa). Em

\footnotetext{
2 "The lived body is understood in terms of its practical engagement with the world."

3"The bodily space is a space of actions endowed with existential meanings, of ways of existing towards objects. The body schema therefore consists in a sensorimotor function rather than a sensorimotor representation."
} 
outros termos, o esquema corporal, em suas ações originárias, é uma função existencial, e, não, uma representação de movimentos articulados previamente no intelecto. Devemos, contudo, diferenciar tais ações originárias às quais nos referimos agora das ações intencionais que falaremos mais tarde. Estas, sim, são "produtos" da intencionalidade de um sujeito que atribui sentidos às suas atitudes.

O que queremos expor aqui é que "há como que um germe de movimento que só secundariamente se desenvolve como percurso objetivo." (MERLEAU-PONTY, 2011, p. 138). Isto é, é próprio do ser no mundo este entrelaçamento com seu mundo que o torna parte integrante deste e que sua liberdade em direção às suas atitudes é, antes de qualquer coisa, primitivas assim como sua existência. É com esta "esfera primitiva" de ser no mundo que passo a agir de forma intencional quando almejo uma certa finalidade. Sendo assim, o corpo próprio traz o ser no mundo em seu invólucro já encarnado no seu mundo circundante. Ser no mundo e corpo são, portanto, equivalentes a esta vivência constantemente vívida.

O ser primitivo, o ser originariamente nascido e atuante no seu mundo vivido, é um ser cuja sua existência é anteriormente dada. Antes de eu ser consciente de qualquer juízo que possa fazer, já sou no mundo. Assim, por exemplo, Merleau-Ponty relata que o psicólogo, ao falar de si mesmo e de sua relação para com o mundo, já traz em si, de antemão, toda esta bagagem da qual se fala. Vejamos:

Mas, enquanto psicólogo falando de psiquismo, ele era tudo aquilo de que falava. Essa história do psiquismo que ele desenvolvia na atitude objetiva, ele já possuía seus resultados diante de si, ou antes, em sua existência, ele era seu resultado contraído e sua recordação latente. A união entre a alma e o corpo não se realizara de uma vez por todas e em um mundo distante, a cada instante ela renascia abaixo do pensamento do psicólogo, e não como um acontecimento que se repete e a cada vez surpreende o psiquismo, mas como uma necessidade que o psicólogo previa em seu ser ao mesmo tempo em que a constatava pelo conhecimento. (MERLEAU-PONTY, 2011, p. 141) (grifos do autor)

Esta junção discernível - mas inseparável - entre corpo e psiquismo não pode ser fundada numa ligação objetiva, que possamos constatar por meio de métodos psicológicos. É uma união que põe o ser no mundo no mesmo patamar, por assim dizer, do próprio mundo que nele está impregnado. Não podemos aqui compará-los um ao outro substancialmente. Todavia, devemos frisar sua correlação e equivalência no que concerne à forma do indivíduo se portar diante das atribulações corriqueiras. Isto é, as atitudes "naturantes" do ser no mundo são sempre embasadas na sua característica de ser com o mundo, de ter uma abertura imperceptível e natural a este, quase que mágica, uma abertura de vazão e de recebimento das afecções mundanas. O ser no mundo é, então, como um rio, que, ao estar em constante correnteza, recebe água de seus afluentes e sempre encontra e faz um caminho de canalização. É a esta duplicidade existencial, uma ontologia ambígua, que queremos relacionar o ser no mundo: ao mesmo tempo em que ele é afetado pelo mundo, também afeta este por meio de seu estado de perpétuo fazer-se, estar-aí, mover-se, ser-se. 


\section{A SÍNTESE CORPORAL DO CORPO PRÓPRIO}

O corpo próprio é dotado de um "poder habitual", o qual se manifesta como comunicação primordial com ambiente em que está situado. Esta habitualidade conduz o ser no mundo numa corporificação que se torna indistinta do seu meio, isso no que concerne ao fato de o corpo próprio se pactuar com o mundo vivido de tal forma que seus modos de agir, de caminhar e de sentir este se tornam ambivalentes. Isto é, dirijo-me o mundo a partir da referência do meu corpo. Meus movimentos em direção ao mundo se dão em consonância com as afecções que este me proporciona e eu me ligo em uma posição de similaridade com ele. Em outras palavras, quando nos movimentamos ou queremos fazer alguma atividade, nosso corpo é a referência que temos para que seja possível - ou não - tais movimento e ação. Assim, se referindo a um penhasco rochoso e à possibilidade de sua escalada, e com base na corporeidade defendida por MerleauPonty, Reynolds (2013, p. 179-180) afirma:

Ao se ajustar às particularidades de seu ambiente, meu corpo mantém ao meu
redor intenções que não são dependentes de minhas escolhas e decisões, e
Merleau-Ponty argumenta que não podemos concebê-lo de modo que as
montanhas sejam pequenas para nós. Ele sugere que mesmo que imaginemos que
estejamos vendo as montanhas da perspectiva de uma montanha muito maior,
nossas mãos e pés ainda são nosso ponto de referência para darmos esse salto
imaginativo.

Podemos ver aqui que não somos dependentes apenas de nós mesmos para agirmos no mundo. Somos dependentes desta ambivalência entre corpo e mundo. O mundo também "dita" como podemos executar determinadas ações em virtude de nosso ponto referencial corporal. Por exemplo, se estou à beira de um precipício, prestes a pular para o outro lado sem que caia no abismo, a partir da minha noção corporal e de sua motricidade, ambas evidenciadas pelo hábito da onipresença do meu corpo a mim, é que posso empreender o pulo ou a desistência.

O mundo é um polo de ação que "impõe" ao Eu corporificado uma atitude. Em outras palavras, o mundo está sempre aberto para que ajamos nele, uma vez que não podemos estar no mundo sem que nossas ações nunca remetam a ele. Devemos entender por "impor", neste caso, como o modo de o mundo se comportar em relação ao sujeito encarnado, ou seja, como um campo de ação sobre o qual todas as minhas atitudes necessariamente devem ser.

A patologia de Schneider, analisada por Merleau-Ponty, cujo paciente, devido a um acidente de guerra no qual estilhaços de obus afetam sua cabeça, perde a sua habitualidade corporal e passa a experienciar apenas seu corpo atual, ilustra a melodia harmoniosa e sincronizada com o mundo enquanto somos "sujeitos normais" - ou saudáveis. Uma vez perdida esta harmoniosidade, perdemos a característica de nos movimentarmos de forma que não precisemos "intelectualizar" cada gesto. Em suma, um doente tal qual Schneider, numa situação de movimentação do braço, "deve primeiramente 'encontrar' seu braço, 'encontrar' o gesto pedido por movimentos preparatórios, o próprio gesto perde o caráter melódico que apresenta na vida usual e torna-se visivelmente uma soma de movimentos parciais laboriosamente postos lado a lado." (MERLEAU-PONTY, 2011, p. 152). Assim, vemos que um simples movimento, que o sujeito saudável praticaria de forma habitual e sem a necessidade de raciocinar cada passo, o sujeito doente precisa de um aparato intelectual para realizá-lo.

No que concerne ao hábito corpóreo, os movimentos realizados tornam-se, por assim dizer, uma extensão deste corpo habituado a praticar gestualidades como prática vital. Em outros 
termos, a síntese do corporal próprio - unidade que se estabelece por meio da relação corpomundo-outro -deum sujeito saudável é tal que seus movimentos são coextensivos, como resposta direta, com o mundo; é uma propriedade inerente do ser no mundo, que se relaciona com o próprio corpo e com os fatos mundanos. Isto é, o alcance do meu corpo, por meio de movimentos habituais, próprios de um ser que dispõe de todas as habilidades corporais e que não precisa mais racionalizar cada uma em separado e de antemão, é um alcance que já está predisposto à minha ação presente e futura. Quando almejo alcançar um objeto qualquer, por exemplo, em virtude da conjuntura do meu corpo e da minha noção particular da espacialidade dele, posso conceber qual movimento farei num todo para tal efeito, sem que seja preciso eu "testar" meus membros antes para saber se sou capaz de conseguir o objetivo desejado. Nestes termos, "a experiência de meu corpo é uma experiência unitária." ${ }^{4}$ (MAZZÙ, 2001, p. 47, tradução nossa). Assim,

por meio de meu corpo enquanto potência de um certo número de ações familiares, posso instalar-me em meu meio circundante enquanto conjunto de manipulanda, sem visar meu corpo nem meu meio circundante como objetos no sentido kantiano, quer dizer, como sistemas de qualidades ligadas por uma lei inteligível, como entidades transparentes, livres de qualquer aderência local ou temporal e prontas para denominação ou, pelo menos, para um gesto de designação. Há meu braço como suporte desses atos que conheço bem, meu corpo como potência de ação determinada da qual conheço antecipadamente o campo ou o alcance, há meu meio circundante como conjunto dos pontos de aplicação possíveis dessa potência. (MERLEAU-PONTY, 2011, p. 152-153, grifo do autor).

A experiência do conjunto do corpo próprio, somado com o meio circundante no qual está inserido e é inseparavelmente nele, permite ao Eu encarnado realizar movimentos que são "magicamente" pré-concebidos e executados sem os ditames de uma inteligibilidade direcionada a cada gesto individual. O meu corpo, portanto, se mistura ao mundo e, assim, eu passo a ser e a viver numa sincronia vivida, que não mais recorre à consciência de cada parte de meu corpo para poder, apenas a partir disso, movimentar-me. Este "misturar-se" não significa que somos ontologicamente idênticos ao mundo. Como já frisamos anteriormente, somos, paradoxalmente, distinguíveis do mundo e, ao mesmo tempo, inseparáveis deste. Misturamo-nos no sentido em que incorporamos nossa vivência constante ao ponto de nosso corpo e o mundo não serem mais estranhos um ao outro. Há um entrançamento original entre sujeito e mundo. Minha corporeidade torna-se quase que mundana, ou seja, minha experiência sensível de meu corpo e do mundo, assim como meus movimentos intencionais, são sentidos e executados quase que trivialmente. Devido à "enformação" corporal e ao hábito de estarmos sempre situados num meio qualquer, produzimos atitudes corporais que se adéquam ao momento pelo qual passamos. Atitudes tais que não passam pelo crivo do intelecto, no que diz respeito ao conhecimento da própria corporeidade.

A síntese do corpo próprio, portanto, é um referencial que está sempre com o sujeito, aquém de qualquer conscientização que possamos fazer dela. Está com o sujeito em vez de ser para o sujeito, ou seja, experiencio meu corpo não como uma coisa que é para mim, mas, antes, o experiencio como algo que sou eu mesmo, impossível de desvencilhá-lo. Assim, um "sujeito normal", livre de uma patologia ao modo de Schneider,

tem imediatamente "pontos de apoio" em seu corpo. Ele não dispõe de seu corpo apenas enquanto implicado em um meio concreto, não está em situação apenas a respeito das tarefas dadas de um ofício, não está aberto apenas para as

4 “l'expérience de mon corps estuneexpérienceunitaire." 
situações reais, mas tem, além disso, seu corpo, enquanto correlativo de puros estímulos desprovidos de significação prática, está aberto a situações verbais e fictícias que pode escolher ou que um experimentador pode propor-lhe. (MERLEAU-PONTY, 2011, p. 156).

Esta unidade corpórea, esta experiência unitária de corpo e espacialidade no âmbito da situação do sujeito no espaço, é a "enformação" das práticas que uma pessoa normal realiza sem que seja preciso direcionar-se, conscienciosamente, para cada gesto em particular para, daí, poder executar os movimentos desejados. Em suma, quando realizamos movimentos no seio do mundo, temos uma noção impregnada, em virtude da experiência habitual de nosso corpo com seu mundo vivido, do que podemos alcançar e do que podemos fazer a partir do nosso ponto de referência. Além disso, os nossos gestos não são meticulosamente medidos intelectualmente para que possamos executá-los, e, assim, nosso corpo não toma o lugar de figura exterior a um Eu, como é no caso da patologia de Schneider: "a doença de Schneider consiste justamente em precisar fazer com que a parte tocada de seu corpo passe ao estado de figura, para saber onde o tocam." (MERLEAU-PONTY, 2011, p. 156-157). Dessa forma, a espontaneidade dos movimentos, no caso de Schneider, dá lugar a outros movimentos anteriormente preparatórios para o fim almejado ser possível, isto é, para que o doente execute um movimento que no cotidiano fazemos com naturalidade, é preciso que ele empreenda uma série de gestos "propedêuticos" para experienciar e "conhecer" seu próprio corpo. Assim, "[e]le não consegue destacar seu corpo das situações do cotidiano e agir segundo a virtualidade das situações" (FERRAZ, 2006, p. 97). O doente perde, com isso, a capacidade de sobrevoo perante seus movimentos para poder executá-los de forma "naturalizada"5.

A doença de Schneider não pode ser considerada de cunho motor e nem de cunho intelectual. Ambos os aspectos estão visivelmente inalterados, embora mais complicados para executá-los. Uma vez que o paciente pode levar sua mão, por exemplo, ao ponto desejado, não podemos aqui atribuí-lo uma deficiência motora; por outro lado, se é dado um objetivo para ele desenvolver, e ele o faz, não podemos afirmar uma limitação intelectual. Vemos que tanto motora como intelectualmente Schneider não está impossibilitado. Assim, "é preciso reconhecer um núcleo pessoal que é o ser do doente, sua potência de existir." (MERLEAU-PONTY, 2011, p. 188). Portanto, antes que nos direcionemos para estes dois aspectos equivocadamente supostos de residência da doença, é preciso se dar conta do ser do doente, o qual é anterior a estas manifestações motoras e intelectuais. Há, nisso, uma dimensão pré-reflexiva do sujeito.

A partir de uma análise existencial da patologia de Schneider é que podemos compreendêla de forma satisfatória e que recuse as explicações tanto intelectualistas como empiristas. Aos intelectualistas, a doença seria uma limitação do intelecto - interoceptivo - como já mencionamos. Para os empiristas, por outro lado, seria, talvez, um entrave físico - exteroceptivo. A análise existencial de Merleau-Ponty alega a incapacidade de o "arco intencional" do paciente unir os fatores existenciais que demandam uma vivência comum igual aos demais "sujeitos normais". Este arco intencional

projeta em torno de nós nosso passado, nosso futuro, nosso meio humano, nossa situação física, nossa situação ideológica, nossa situação moral, ou antes que faz

\footnotetext{
${ }^{5}$ Devemos entender a palavra "naturalizada", neste contexto, como sinônimo de "habitual" ou "habitualizada", ou seja, quando um movimento corporal, por exemplo, torna-se efetivo sem que precisemos formulá-lo anterior e integralmente no pensamento.
} 
com que estejamos situados sob todos esses aspectos. É este arco intencional que faz a unidade entre os sentidos, a unidade entre os sentidos e a inteligência, a unidade entre a sensibilidade e a motricidade. É ele que se "distende" na doença. (MERLEAU-PONTY, 2011, p. 190).

Perdendo esta capacidade de unidade entre todos estes aspectos fundamentais da existência humana, o doente destaca-se da sua situação habitual, já que seu passado não tem mais a importância devida para a manutenção de suas atitudes corriqueiras e naturalizadas. Desse modo, o sujeito doente está isolado na atualidade corpórea, na qual a síntese existencial, produzida pelo arco intencional citado por Merleau-Ponty, para de operar. Perdendo esta operação de unificação que citamos acima, a consciência - que é sempre consciência de algo e, para que seja, é preciso que haja algo do qual ela seja esta consciência - passa a "exercer sua função" sem o alicerce, por assim dizer, espontâneo, que faz com que ela execute ações intuitivas adquiridas por seu modo habitual de vivências. O caráter da consciência, neste sentido, tem suas atribuições num campo pessoal que serve de fundamento para sua operação, isto é,

a consciência projeta-se em um mundo físico e tem um corpo, assim como ela se projeta em um mundo cultural e tem hábitos: porque ela só pode ser consciência jogando com significações dadas no passado absoluto da natureza ou em seu passado pessoal, e porque toda forma vivida tende para uma certa generalidade, seja a de nossos hábitos, seja a de nossas "funções corporais". (MERLEAU-PONTY, 2011, p. 192).

O paciente, portanto, livre das amarras de seu passado pessoal e, assim, "desabitualizado", torna-se "um observador distante para si mesmo." (REYNOLDS, 2013, p. 168-169).

A coisa a ser percebida, por meio dos movimentos de nosso corpo, é um referencial perceptivo incorporado por nós mesmos e as ações em direção a ela é uma mistura de corporeidade e de mundaneidade. Em outras palavras, nosso corpo e as coisas que estão à nossa volta e ao nosso alcance mantêm uma relação interativa, na qual um exerce "influência" sobre o outro. Quando, por exemplo, movo meu braço em direção à tela do meu computador, movo-o "sabendo" pressupostamente que o alcançarei e que ela está ali para ser tocada (tendo em vista que sou um "sujeito normal" e livre de alucinações). Dessa forma,

um movimento é aprendido quando o corpo o compreendeu, quer dizer, quando ele o incorporou ao seu "mundo", e mover seu corpo é visar às coisas através dele, é deixá-lo corresponder à sua solicitação, que se exerce sobre ele sem nenhuma representação. [...] Para que possamos mover nosso corpo em direção a um objeto, primeiramente é preciso que o objeto exista para ele. (MERLEAU-PONTY, 2011, p. 193).

Por meio da síntese do corpo próprio, os movimentos apreendidos habitualmente em virtude das generalidades corporais que executamos cotidianamente são incorporados num mundo próprio do Eu encarnado. "Mundo próprio" no que concerne à sua própria noção de espacialidade e de habilidades particulares. A "enformação" corporal, neste caso, é a conjuntura que o sujeito adquire em sua vivência constante em seu mundo vivido. Tal "enformação" compreende todos os movimentos triviais - que não necessitam de representação prévia no intelecto - que produzimos a fim de dar vazão às nossas atitudes enquanto seres moventes. Assim, resumindo o que temos dito, "[a] experiência motora de nosso corpo não é um caso particular de conhecimento; ela nos fornece uma maneira de ter acesso ao mundo e ao objeto, 
uma 'praktognosia' que deve ser reconhecida como original e talvez como originária." (MERLEAUPONTY, 2011, p. 195). Esta praktognose é a incorporação que nossa corporeidade adquire com suas práticas constantes e corriqueiras, as quais passam a ter seu caráter intrínseco ao sujeito correspondente. Pois, uma vez incorporados, habitualmente, as gestualidades e movimentos, "[m]eu corpo tem seu mundo ou compreende seu mundo sem precisar passar por 'representações', sem subordinar-se a uma 'função simbólica' ou 'objetivante'." (MERLEAUPONTY, 2011, p. 195). Esta subordinação à qual o autor se refere é a que Schneider alude, ou seja, seus movimentos precisam passar pelo crivo de um pré-reconhecimento gestual, como já frisamos.

A fluência vital, à qual damos o nome de "hábito", é a forma de que nosso corpo próprio se adéqua ao mundo, que se crava no seio do mundo e se abre a este. O hábito é uma "característica" que foge às explicações espaciais comuns, ou seja, não podemos constatar a consciência da localização de nosso braço num espaço objetivo, mensurável. Pois, a nossa habitualidade corporal é

um saber que está nas mãos, que só se entrega ao esforço corporal e que não se pode traduzir por uma designação objetiva. $O$ sujeito sabe onde estão as letras do teclado, assim como sabemos onde está um de nossos membros, por um saber de familiaridade que não nos oferece uma posição no espaço objetivo. 0 deslocamento dos seus dedos não é dado ao datilógrafo como um trajeto espacial que se possa descrever, mas apenas como uma certa modulação da motricidade, distinta de qualquer outra por sua fisionomia. (MERLEAU-PONTY, 2011, p. 199).

Esta motricidade adquirida pelo hábito resume-se na compreensão do corpo para com a coisa visada, isto é, experienciamos o elo entre o que nos é dado e o que visamos. Em outros termos, quando almejamos alcançar uma coisa nos aparecida, vamos ao encontro dela de uma forma motriz quase que mágica, sem calcularmos objetivamente o caminho a percorrer e o espaço entre meu corpo e aquilo visado. Este elo entre mim e a coisa, entre mim e o mundo, é a compreensão corporal que forma nossa motricidade naturalizada, através não de nosso corpo objetivo, mas de nosso "corpo como mediador de um mundo." (MERLEAU-PONTY, 2011, p. 201).

O corpo próprio, canal de expressão do ser no mundo, dá sentido aos movimentos que conservam a sua vida. Por meio da expressividade corpórea, adquirida pela generalidade vivida em seu meio circundante, o corpo expõe gestualidades como significações do ser no mundo. Assim, o corpo próprio é "o movimento de expressão, aquilo que projeta as significações exterior dandoIhes um lugar, aquilo que faz com que elas comecem a existir como coisas, sob nossas mãos, sob nossos olhos." (MERLEAU-PONTY, 2011, p. 202). Com isso, tendo em vista que o corpo, irremediavelmente, mediador entre nosso ser e o mundo, somos esta expressividade constante que carrega significações que fazem com que tenhamos um mundo para nós e operemos nele como manutenção da nossa vivência.

A espacialidade corporal, enquanto conjunto de significações, é o modo primordial do corpo, ou seja, este contempla seus contornos próprios como um modo de existência com o qual se move autenticamente no mundo, sem que seja preciso conhecer seu corpo parte por parte. Em outras palavras, o corpo próprio traz consigo a noção de sua própria espacialidade, da qual não se separa. Mesmo quando uma sensação corpórea distorcida, promovida por um distúrbio qualquer, afeta a forma de sentir a espacialidade de si mesmo, a síntese corporal não se desvincula da efetivação da existência no espaço. Em suma, quando um anosognósico ou um paciente com membro fantasma sentem seus membros doentes ou amputados como objetivamente estando ali, 
tal sensação mostra que a síntese do corpo próprio é expressão dinâmica do ser no mundo. 0 corpo, portanto, habita o espaço. Assim, quando

\begin{abstract}
os doentes sentem o espaço de seu braço como estranho, se em geral eu posso sentir o espaço de meu corpo enorme ou minúsculo, a despeito do testemunho de meus sentidos, é porque existe uma presença e uma extensão afetivas das quais a espacialidade objetiva não é condição suficiente, como o mostra a anosognosia, e nem mesmo condição necessária, como o mostra o braço fantasma. (MERLEAU-PONTY, 2011, p. 206).
\end{abstract}

Com isso, a espacialidade objetiva não pode ser caracterizada como um meio pelo qual explicamos nossa conjuntura corporal própria. Nosso corpo mantém uma relação particular e inerente com nosso ser. E é por esta relação de "proximidade" extrema, de inseparabilidade, que o ser no mundo torna-se o que é, ou seja, abertura para o mundo e polo de significações e movimentos que sempre visam algo fora de si. Isso nos leva a entender que a "espacialidade do corpo é o desdobramento de seu ser de corpo, a maneira pela qual ele se realiza como corpo." (MERLEAU-PONTY, 2011, p. 206). Assim, a consciência espacial do corpo próprio não é uma consciência objetiva, na qual eu delineio os contornos precisos de meu corpo e sei, com isso, onde ele está situado, da mesma forma que concebo a garrafa de água sobre minha mesa. A espacialidade corpórea a que o autor se refere é tal que não passa pela mensurabilidade das partes que me compõem, e, sim, é a capacidade de nos movermos e de estarmos no mundo de modo que nossa ação motriz seja uma ação espontânea e que nossos gestos sejam resultados da disponibilidade de um corpo que nos está presente todo o tempo por meio de uma corporificação habituada. Em resumo, a onipresença de nosso corpo a nós mesmos mostra que "os movimentos do corpo são desenvolvidos quase sem esforço consciente." (REYNOLDS, 2013, p. 175), isso no que concerne, como já afirmamos anteriormente, a não conscientização de cada parte do corpo para, a partir disso, gerar um movimento determinado. Nosso ser no mundo convive com situações corporais particulares que se adaptam à necessidade requerida de cada momento bem como ao seu ambiente.

A síntese do corpo próprio é a significação pela qual nos situamos no mundo. Através das gestualidades naturalizadas de nosso corpo damos sentidos à nossa vivência no seio do mundo. $O$ corpo sujeito, nesta perspectiva, abrange toda a gama de sentidos que os movimentos do ser no mundo realiza. Esta conjuntura corporal é a "imagem" de uma totalidade que nada significa se desmembrá-la, isto é, como em Saussure, no que concerne à linguagem, "os signos um a um nada significam." (MERLEAU-PONTY, 2013, p. 59), também o é assim para a corporeidade do ser no mundo. Minha mão, sem estar atrelada a um movimento em direção ao mundo, nada mais é que um membro que compõe meu corpo físico. Todavia, se levo ela em direção ao teclado de meu computador para digitar este texto, passa a ser uma unidade corpórea significativa, que me permite acessar o mundo por meio de movimentos intencionais e resultantes de uma ação corporificada. Esta ação, portanto, não pode ser expressa pela exclusividade de minha mão que apalpa as teclas ou pela ligação de meu intelecto a tal membro. Minha unidade corporal produz esta configuração de meu corpo que não pode ser exclusividade de uma parte em especial. Por isso, "[n]ão é ao objeto físico que o corpo pode ser comparado, mas antes à obra de arte. Em um quadro ou em uma peça musical, a ideia só pode comunicar-se pelo desdobramento das cores e dos sons." (MERLEAU-PONTY, 2011, p. 208).

A estrutura do corpo próprio, esta síntese corporal que somos enquanto sujeito que visa o seu mundo em que está situado, mantém a relação entre um psiquismo e uma vivência enraizada 
na objetividade do ser no mundo e do mundo vivido. Isto é, somos um nó de significações pelo qual perpassam todas as nossas formas de nos relacionarmos com tudo o que está à nossa volta. Se somos aquilo pelo qual o mundo existe para nós, é porque somos relação permanente para com as coisas que nos rodeiam. Sendo assim, nosso corpo produz significações que o levam para sua adequação existencial no seio do mundo. A percepção é a "pedra de toque" para tal postura do ser no mundo:

\begin{abstract}
Aprender a ver as coisas é adquirir um certo estilo de visão, um novo uso do corpo próprio, é enriquecer e reorganizar o esquema corporal. Sistema de potências motoras ou de potências perceptivas, nosso corpo não é objeto para um "eu penso": ele é um conjunto de significações vividas que caminha para seu equilíbrio. (MERLEAU-PONTY, 2011, p. 212).
\end{abstract}

Dessa forma, nosso corpo não pode ser entendido como um "depósito" que é tomado por um espírito e que este é a referência para todas as percepções, até mesmo as do próprio corpo. 0 corpo próprio, pelo contrário, é o referencial, por assim dizer, pelo qual seus movimentos e sua percepção do mundo circundante e de si próprio têm uma significação comum no que se refere à forma do ser no mundo. Em outras palavras, perceber e, por meio disso, intencionalmente explorar o mundo é a forma mais primordial que o sujeito encontra de se ajustar ao seu meio. Um ajuste, portanto, originário, que não é advindo por intermédio de um mecanicismo que racionaliza cada atitude de ajuste, mas, sim, por um modo de integridade entre o Eu encarnado que somos e nosso mundo vivido.

\title{
4 O CORPO PRÓPRIO E SEUS DESDOBRAMENTOS
}

A coexistência com o mundo e com os outros enraíza o corpo próprio como veículo do ser no mundo. Os projetos do corpo próprio não são apenas realizações dele isoladamente, mas projetos frutos da sua condição de ser no mundo que produzem projetos compartilhados. Desses projetos emergem atos regidos por determinações anônimas e pessoais.O exemplo disso, concernente à sexualidade, o ser no mundo se projeta no mundo e forma, assim, sua história pessoal. Em outras palavras, a sexualidade é esta capacidade de o humano se lançar nas situações de sua vida e de reorganizá-las. Não podemos confundir, neste contexto, a sexualidade como um fator exclusivamente genital, como o senso comum costuma aludir, mas, antes, ela é uma "energia" que pulsa e conduz o ser no mundo a construir sua própria história, pois "ela [a sexualidade] é o poder geral que o sujeito psicofísico tem de aderir a diferentes ambientes, de fixar-se por diferentes experiências, de adquirir estruturas de conduta. É a sexualidade que faz com que um homem tenha uma história." (MERLEAU-PONTY, 2011, p. 219). Esta "energia" que é a sexualidade advém, é claro, do corpo enquanto sujeito pré-reflexivo, ou seja, produzimos objetivamente pulsões que nos lançam em direção ao exterior de nós mesmos. Dessa forma,

A região dos sentimentos e pulsões exibe a função de projeção do ser no mundo sem apresentar seu resultado como independente da infra-estrutura existencial humana, como ocorre com a função espacial; tal região permite elucidar mais facilmente a atividade de organização de um meio como um campo de vivências significativas. (FERRAZ, 2006, p. 100, grifos do autor). 
Portanto, por meio das pulsões, a sexualidade mantém o ser no mundo voltado à construção constante de sua história pessoal e dando-Ihe significações para a sua apropriação. Ela também não pode ser reduzida a um aspecto particular pelo qual o ser no mundo se vale para existir significativamente. Se juntarmos todos os sentidos e os desdobramentos do corpo, vemos que "a visão, a audição, a sexualidade e o corpo não são apenas pontos de passagem, os instrumentos ou as manifestações da existência pessoal: esta retoma e recolhe em si aquela existência dada e anônima." (MERLEAU-PONTY, 2011, p. 221). Com isso, é sabido que a existência pessoal não é o apoderar-se de cada um dos sentidos ou mesmo da sexualidade. Isto é, não são os sentidos ou a sexualidade que fazem da história de um homem um produto exclusivo seu, mas a existência própria de tal homem é a reciprocidade de todos os sentidos, das pulsões e do corpo para que o ser no mundo, por meio de sua unidade psíquica e carnal, promova sua historicidade. Esta relação intrínseca pode ser entendida, segundo Merleau-Ponty, a partir da compreensão de "expressão" e "significação", ambas referentes à linguagem e ao pensamento, respectivamente.

No campo expressivo e significativo podemos perceber uma disposição do ser através de sua capacidade de coexistir com o mundo e com outrem. Na análise mostrada por Merleau-Ponty de uma paciente afônica, após ser privada, por sua mãe, de ver o rapaz a quem ama, nos damos conta de que a expressividade - neste caso, a fala - é a conduta que nos permite ser com o mundo e com os outros. Assim,

Se a emoção escolhe exprimir-se pela afonia, é porque a fala é, dentre todas as funções do corpo, a mais estreitamente ligada à existência em comum ou, como diremos, à coexistência. A afonia representa uma recusa da coexistência, assim como, em outras pessoas, a crise nervosa é o meio de fugir da situação. (MERLEAU-PONTY, 2011, p. 222).

A partir disso, vemos que a fala, enquanto veículo de relações para com os outros, é tanto acesso ao outro como recusa de interação e a reclusão de si próprio, no caso da afonia. Portanto, a afonia - tendo em vista que a moça em questão não simplesmente deixa de falar, mas perde a voz - é uma supressão do ser no mundo, isto é, é o "enclausuramento" do ser quando perde de vivenciar aquilo desejado e se retrai a seu próprio anonimato, embora não seja uma situação buscada e desejada pelo sujeito. Esta situação da afonia é empreendida abaixo da consciência posicional, ou seja, tornar-se afônico não é compreendido por meio da consciência da origem da afonia, como se fosse um fato objetivo e verificável através de uma sondagem psicológica. Portanto, é parte da condição humana o ser genérico, que se perde na generalidade existencial e incumbe-se nas mais variadas formas de se resguardar de situações indesejadas. Dessa forma,

Sono, despertar, doença e saúde não são modalidades da consciência ou da vontade, eles supõem um "passo existencial". A afonia não representa apenas uma recusa de falar, a anorexia uma recusa de viver, elas são essa recusa do outro ou essa recusa do futuro arrancadas da natureza transitiva dos "fenômenos interiores", generalizadas, consumadas, tornadas situações de fato. (MERLEAUPONTY, 2011, p. 227).

Com isso, o movimento transitório que deveria ser comum ao ser no mundo é cindido pela recusa de ultrapassagem de um problema ou de um momento. Tornar-se recluso em si próprio é permanecer em seu tempo pessoal, fechado à transitoriedade existencial pela qual cada um necessariamente passa. Sendo assim, o corpo mantém esta duplicidade que ora nos permite ir ao 
encontro do mundo e dos outros, ora torna-se o cativeiro de nós mesmos. Em outras palavras, meu corpo é a expressividade e a não-expressividade da minha existência enquanto sujeito autônomo. Quando permaneço aberto a todas as situações que o mundo (e eu mesmo) me impõe, meu corpo expressivo é o conduto relacional de mim para com meu exterior; ao contrário, quando, devido a algum trauma tal qual o da moça que expomos, sou impelido a me retrair quase que inexplicavelmente, meu corpo passa a ser a prisão anônima do meu Eu, um Eu que resiste em exteriorizar-se. Uma vez retraído, como no caso da afonia, no qual minha fala deixa de ser relação com outrem, deixo de lado minha existência pessoal e passo a viver na generalidade que me proíbe de manifestar-me enquanto um ser em situação, ou seja, um ser pessoal.

Meu corpo, então, pode ser tanto objetivado como pessoalizado ao olhar do outro. Para um destes, ou seja, se sou objeto ou pessoa para outrem, é preciso que haja uma significação metafísica na relação que eu mantenha com ele. Em outros termos, se, ao olhar de um terceiro sobre meu corpo, eu ajo de forma a me submeter à sua investida de desejo ou me imponho para tornar-me fascinação para ele, torno-me escravo e senhor, respectivamente. Em suma, a significação metafísica que emana desta relação de mim para com outro é quem "dita" como me sentirei enquanto ser corporificado. Portanto,

Dizer que tenho um corpo é então uma maneira de dizer que posso ser visto como um objeto e que procuro ser visto como sujeito, que o outro pode ser meu senhor e meu escravo, de forma que o pudor e o despudor exprimem a dialética da pluralidade das consciências e que eles têm sim uma significação metafísica. (MERLEAU-PONTY, 2011, p. 231).

Assim, quando sou tomado por um olhar que parece roubar-me de mim mesmo, perco a minha pessoalidade ante a investida daquele que me "possui" e desapareço no anonimato do meu corpo. Ao contrário, se eu reverto a significação do olhar do terceiro e passo a "possuí-lo" enquanto uma fascinação para ele, torno-me senhor, ou seja, uma pessoalidade a qual, para ele, não se reduz mais apenas ao objeto corpóreo, e, sim, a um Eu encarnado que atribui sentidos e significações que podem envolvê-lo. Isso, dirigido à sexualidade, nos mostra que ser sexual e ser pessoal são indistintos, uma vez que a energia pulsional que me crava no mundo constantemente ora me torna um ser genérico, ora me torna um ser pessoal. Estas mudanças, estes sentidos que o ser no mundo dá a si próprio, ao mundo e ao outro são as formas que encontra para se firmar e construir sua própria história. No caso da afonia da paciente apresentada por Merleau-Ponty, a sexualidade, por se tratar da privação de encontro com seu amante, prova esta reciprocidade entre ela e a nossa existência geral. Isto é,

Existe osmose entre a sexualidade e a existência, quer dizer, se a existência se difunde na sexualidade, reciprocamente a sexualidade se difunde na existência, de forma que é impossível determinar, para uma decisão ou para uma dada ação, a parte da motivação sexual e a parte das outras motivações, é impossível caracterizar uma decisão ou um ato como "sexual" ou "não-sexual". (MERLEAUPONTY, 2011, p. 234).

Vemos, com isso, que a sexualidade se ramifica por toda a existência pessoal e pode ser concebida como necessidade existencial, no sentido de que faz parte da existência geral do ser humano, ou seja, indissociável desta. Não se pode conceber um homem sem sexualidade, pois, se 
assim fosse, seria tão "inconcebível quanto um homem sem pensamento." (MERLEAU-PONTY, 2011, p. 235). Assim,

todas as "funções" no homem, da sexualidade à motricidade e à inteligência, são rigorosamente solidárias, é impossível distinguir, no ser total do homem, uma organização corporal que trataríamos como um fato contingente, e outros predicados que the pertenceriam com necessidade. (MERLEAU-PONTY, 2011, p. 235).

Os fatos necessários, neste caso, são os modos com os quais o homem elabora sua existência pessoal; sem eles, o homem não seria tal qual o concebemos e não poderia ser atribuído a ele a nossa compreensão de humano. Em outras palavras, o corpo próprio e seus modos de vivência trazem consigo a necessidade de que é preciso inventar sua própria história para se pessoalizar. A contingência, por outro lado, entende-se pelo "sentido em que esta maneira humana de existir não está garantida a toda criança humana por alguma essência que ela teria recebido em seu nascimento." (MERLEAU-PONTY, 2011, p. 236). Sendo assim, percebemos que Merleau-Ponty preocupa-se com o fato que cada sujeito dá sentido à sua existência de forma individualizada, isto é, o Eu encarnado encontra, na sua situação de fato, sempre novas formas de refazer-se e de inventar sua historicidade com a liberdade que lhe é possível. Assim, o ser no mundo transforma sua contingência em sua necessidade, ou seja, existir é transformar as nossas aptidões adquiridas em instrumentos de movimento da vida e, com isso, a contingência da maneira humana de existir trazida por nós transforma-se no fator necessário que precisamos para produzirmos a nós mesmos e a nossa história. A produção de uma história pessoal tem, para Merleau-Ponty, uma relação direta com o tema da expressividade.

\section{A EXPRESSIVIDADE}

A expressividade por meio da fala nos mostra que esta é uma ação, ao invés de a palavra ser apenas um invólucro sem significado inerente. Para o intelectualismo, a fala é uma ação de um sujeito pensante que, através das associações adquiridas, dá à coisa uma imagem verbal mais adequada e que visa à universalidade essencial daquilo a nomear. Neste sentido, a palavra não passa de uma adequação de uma res cogitans perante a coisa nomeada para torná-la genérica, negligenciando suas particularidades. Em outras palavras, Merleau-Ponty quer nos passar que o intelectualismo prioriza o sujeito pensante e o mantém em primazia ante a fala, isto é, ao expressar-se, ao nomear algo, o sujeito intelectualista suprime o sujeito falante e a fala perde sua característica intrínseca, a saber: a significação enquanto sentido para o mundo, ou seja, a capacidade enformadora do falante ao se relacionar com o mundo.

Para o intelectualismo, fica a questão de como o pensamento pode vir antes da expressão da fala, uma fala interna ou externalizada. Como Merleau-Ponty (2011, p. 241) afirmou:

Um pensamento que se contentasse existir para si, fora dos incômodos da fala e da comunicação, logo que aparecesse cairia na inconsciência, o que significa dizer que ele nem mesmo existiria para si. [...] pensar é com efeito uma experiência, no sentido em que nós nos damos nosso pensamento pela fala interior ou exterior.

O pensamento, portanto, não pode ser concebido antes da fala, uma vez que esta última é a condição pela qual aquele existe e se exprime. Com isso, nosso pensamento só pode ser apropriado e "instrumentalizado" por nós mesmos a partir do momento em que podemos exprimi- 
lo através da linguagem - falada ou escrita. Quando se nomeia uma coisa não significa que aquilo nomeado preexiste em meu espírito, como queriam os intelectualistas. A essência da coisa nomeada reside no próprio nome, isto é, é pela nomeação que o ser no mundo compreende a coisa, como se o reconhecimento fosse o próprio ato de falar dela. Assim,

A denominação dos objetos não vem depois do reconhecimento, ela é o próprio reconhecimento. Quando fixo um objeto na penumbra e digo: "É uma escova", não há em meu espírito um conceito da escova ao qual eu subsumiria o objeto e que, por outro lado, estaria ligado à palavra "escova" por uma associação frequente, mas a palavra traz o sentido e, impondo-o ao objeto, tenho consciência de atingi-lo. (MERLEAU-PONTY, 2011, p. 242).

A expressão é o encontro com o objeto, "é uma modalidade existencial enformadora do mundo." (FERRAZ, 2006, p. 101). O sentido que o falante exprime é a exteriorização do pensamento através da fala. Isso não pode ser confundido como se a fala fosse o "signo" do pensamento, mas, antes, ela e o pensamento são coextensivos e um está entrelaçado no outro. Não podemos conceber pensamento sem linguagem. Assim, "eles estão envolvidos um no outro, o sentido está enraizado na fala, e a fala é a existência exterior do sentido." (MERLEAU-PONTY, 2011, p. 247). Nesta perspectiva, a fala, de um modo geral, é a incorporação do pensamento no mundo, ou seja, quando o ser no mundo se exprime está exteriorizando seu pensamento como forma de adequação e presença subjetiva no mundo. Em resumo, a expressão de um pensamento pelo sujeito se dá pela capacidade de a fala cravar no seio do mundo uma postura particular do emitente.

A expressão, seja na fala ou no gesto corporal em detrimento de algum mal que me assola, é a linguagem do corpo próprio que eu sou. Por isso a fala, assim como a "atividade expressiva" literatura, pintura, etc. -, se enquadra na nossa análise do corpo. Este, por sua vez, como já mencionamos em alguma parte deste trabalho, é o veículo do ser no mundo. Sendo assim, nossa fala é o gesto que esboça nosso pensamento, nossos sentimentos e emoções, assim como o é também as expressões advindas de uma cólera, para falar nos termos de Merleau-Ponty. Não temos um interior ao qual recorremos para depois nos expressarmos. A expressividade é, contudo, a forma autêntica de nos posicionarmos no mundo e de expormos nossa humanidade, enquanto um ser humano. Dessa forma, "eu não percebo a cólera ou a ameaça como um fato psíquico escondido atrás do gesto, leio a cólera no gesto, o gesto não me faz pensar na cólera, ele é a própria cólera." (MERLEAU-PONTY, 2011, p. 251, grifos do autor). Isto é, minha expressão, seja ela qual for, não é um ato que requer uma pré-definição para ser executada, ou seja, minha gestualidade não passa por um "ensaio psíquico" antes de ser expurgada por mim, e, sim, ela é espontânea àquilo que sinto ou àquele pensamento que desejo expor ou, até mesmo, "deixá-lo" comigo.

A fala é a única operação expressiva que finca o ser no mundo intersubjetivamente. A intersubjetividade é amparada, por assim dizer, pela capacidade de sujeitos serem interlocutores um dos outros e transmitirem saber e afecções.

O sentido da palavra se "con-funde" com o pensamento, isto é, pensar não é anterior à gesticulação da fala, mesmo quando esta é silenciada ao próprio sujeito falante, e, sim, a fala é a existência correlativa do pensamento. O pensamento, portanto, é o enunciado que a fala exprime. Então, esta última não é um efeito do pensar: é, todavia, a consumação do pensamento no mundo sensível ou no mundo particular do Eu encarnado enquanto compreensão do seu meio circundante. Dessa forma, 
O que então exprime a linguagem, se ela não exprime pensamentos? Ela representa, ou antes ela é tomada de posição do sujeito no mundo de suas significações. [...] $O$ gesto fonético realiza, para o sujeito falante e para aqueles que o escutam, uma certa estrutura da experiência, uma certa modulação da existência, exatamente como um comportamento de meu corpo investe os objetos que me circundam, para mim e para o outro, de uma certa significação. (MERLEAU-PONTY, 2011, p. 262)(grifo do autor)

O epifenômeno que poderíamos estar propensos a incluir a linguagem enquanto ferramenta exterior do pensamento descaracteriza-se na abordagem merleau-pontyana, isto é, se o pensamento fosse uma anterioridade absoluta à linguagem e esta fosse apenas um efeito secundário daquele, não conceberíamos como podemos pensar sem usar nosso aparato linguístico. Em consonância com isso, a gesticulação humana produz uma modulação existencial que se vincula ao modo de o sujeito encarnado existir em seu mundo vivido de forma a sobreviver, viver e relacionar-se: "[a] linguagem, por sua vez, não coloca outro problema: uma contração da garganta, uma emissão de ar sibilante entre a língua e os dentes, uma certa maneira de desempenhar de nosso corpo deixam-se repentinamente investir de um sentido figurado e o significam fora de nós." (MERLEAU-PONTY, 2011, p. 263, grifos do autor). Vemos, portanto, que a linguagem gestual deixa de ser um modo particular de existência para ser um modo mais universalizado, tendo em vista que quem está fora também pode compreender e dar sentido aos gestos por mim executados. Com isso, meu corpo passa a ser a minha própria investidura a fim de relacionar-me com o mundo e com o outro, sem o qual - meu corpo - eu seria apenas uma quimera. Portanto,

É preciso reconhecer então essa potência aberta e indefinida de significar - quer dizer, ao mesmo tempo de apreender e de comunicar um sentido - como um fato último pelo qual o homem se transcende em direção a um comportamento novo, ou em direção ao outro, ou em direção ao seu próprio pensamento, através de seu corpo e de sua fala. (MERLEAU-PONTY, 2011, p. 263).

Esta abertura por meio do comunicar, qualquer que seja a forma deste, é tal que não passamos a refletir sobre as expressões em si, separadas de seu sentido. Mas, ao contrário:

é ela [a linguagem] que nos lança ao que ela nos significa; ela se dissimula a nossos olhos por sua operação mesma; seu triunfo é apagar-se e dar-nos acesso para além das palavras, ao próprio pensamento do autor, de tal modo que retrospectivamente acreditamos ter conversado com ele sem termos dito palavra alguma, de espírito a espírito. As palavras, ao perderem seu calor, recaem sobre a página como simples signos, e, justamente nos projetaram tão longe delas, parece-nos incrível que tantos pensamentos nos tenham vindo delas. (MERLEAUPONTY, 2012, p. 38-39).

Isso reforça o que tínhamos afirmado antes: a fala, a gestualidade e a linguagem como um todo são a "enformação" do nosso ser no mundo para se manter na dialogicidade com seu mundo vivido e com o outro. Os signos são apenas a tradução sensível do pensamento, de forma que sua existência enquanto partículas objetivas torna-se esquecida quando o que importa é a consumação existencial daquele que os profere. Ao ler este texto, o leitor não atenta para cada signo em particular para daí extrair seu sentido, mas a conjuntura das palavras adquire uma modulação do pensamento do autor, uma vez que pensar e exprimir são indistinguíveis: isso no sentido de estarem inerentemente vinculados ao ponto de um não existir sem o outro no campo das 
significações já estabelecidas, ou seja, de uma língua formulada. Quando alguém lê este texto, ou quando eu leio o texto de outro autor, a sensação é que "[g]raças aos signos sobre os quais o autor e eu concordamos, porque falamos a mesma língua, ele me faz justamente acreditar que estávamos no terreno já comum das significações já adquiridas e disponíveis. Ele se instalou em meu mundo." (MERLEAU-PONTY, 2012, p. 41). O corpo é o meio pelo qual a expressividade da existência humana emana. É ele, portanto, que exprime os gestos que o ser necessita para dar vazão à sua vida de consciência.

Em resumo, o corpo enquanto expressão, no sentido amplo do termo, é a possibilidade, a capacidade e a manutenção da relação vital do ser no mundo. A expressividade é a abertura para a apropriação e para a disseminação de conhecimento do sujeito para com tudo o que ele interage.

\section{CONCLUSÃO}

O corpo próprio, portanto, não pode ser concebido partes extra partes. É preciso vivê-lo e senti-lo como um processo ambíguo, ou seja, ele é consciência, ao mesmo tempo, que é também uma coisa dentre outras no mundo.

No decorrer deste artigo, discorremos sobre as posturas do ser no mundo enquanto ser corpóreo e enquanto corpo como via expressa de sua existência. Diferentemente do intelectualismo, a fenomenologia merleau-pontyana nos conduziu a enxergar o ser efetivamente no mundo e sem desgarrar-se do seu corpo. O corpo não é mais a residência de um espírito, mas a relação de uma subjetividade que não se separa dos processos corporais nem mundanos: porque ela é a própria relação de tudo isso. Com o cartesianismo, nos habituamos a pensar o humano como a existência de duas substâncias separadas relacionando-se entre si, ou seja, a alma e o corpo como uma existência harmoniosa que possibilitaria o homem conhecer o mundo e as coisas.

A tradição cartesiana habituou-nos a desprender-nos do objeto: a atitude reflexiva purifica simultaneamente a noção comum do corpo e da alma, definindo o corpo como uma soma de partes sem interior, e a alma como um ser inteiramente presente a si mesmo, sem distância. Essas definições correlativas estabelecem a clareza de nós e fora de nós: transparência de um objeto sem dobras transparência de um sujeito que é apenas aquilo que pensa ser. (MERLEAU-PONTY, 2011, p. 268).

Para Merleau-Ponty o corpo próprio não pode ser descrito nestas circunstâncias intelectualistas, uma vez que existir tal qual existimos é nos mantermos numa correlação efetiva entre nosso corpo e tudo o que nos envolta. Assim,

A experiência do corpo próprio, ao contrário, revela-nos um modo de existência ambíguo. Se tento pensá-lo como um conjunto de processos em terceira pessoa - "visão", "motricidade", "sexualidade" - percebo que essas "funções" não podem estar ligadas entre si e ao mundo exterior por relações de causalidade, todas elas estão confusamente retomadas e implicadas em um drama único. [...] Ele é sempre outra coisa que aquilo que é, sempre sexualidade ao mesmo tempo que liberdade, enraizado na natureza no próprio momento em que se transforma pela cultura, nunca fechado em si mesmo e nunca ultrapassado. (MERLEAUPONTY, 2011, p. 268-269). 
Este drama comum reúne em si todas as funções do ser no mundo para uma finalidade única, a saber: existir nos conformes de uma liberdade inerente do homem, no sentido de sempre estar fazendo-se e que todas estas funções convergem para tal possibilidade. Não é possível desmembrarmos cada função e entender como elas, em separado, agem na nossa facticidade. 0 emaranhado que somos impossibilita-nos de concluirmos, clara e distintamente, como o quer Descartes, o que cada parte de nós mesmos tem por ação própria, isto é, não conseguimos distinguir em nosso íntimo o que seja da alçada da visão, da motricidade e da sexualidade, quando nos referimos à junção de todas elas. Para produzirmos nossa história pessoal é preciso que haja esta equivalência entre todas as formas corporais e subjetivas do ser no mundo, sem a qual estaríamos reduzidos a meros objetos fechados em si, sem disposição perante o mundo e, por conseguinte, sem construirmos nossa historicidade.

Em suma, o corpo próprio não é o invólucro fechado de uma Consciência, de um Espírito, mas, sim, ele é o meio pelo qual somos, o meio pelo qual nos dispomos no mundo vivido. Ele é a "regência orquestral" de um Eu encarnado que dispensa ações como produtos exclusivos de um Espírito: ele é o sumário de todas as possibilidades, dos órgãos dos sentidos e de todas as partes que o compõe a fim de ser a totalidade por meio da qual, só assim, pode construir-se. Eu não sou o que, determinantemente, penso ser. Eu sou o que, indeterminantemente, eu posso ser através das afecções recíprocas do Eu e do mundo. Para tanto, a síntese do corpo próprio é a possibilidade de se estar sempre posto numa situação concreta e dar sentido a ela.

\section{REFERÊNCIAS}

BARBARAS, Renaud. Investigações fenomenológicas: em direção a uma fenomenologia da vida. Paraná: Editora UFPR, 2011.

DE VIGNEMONT, Frédérique. Bodily Awareness. In: The Stanford Encyclopedia of Philosophy. 2011. Edward N. Zalta (ed.). Disponível em: <http://plato.stanford.edu/archives/fall2011/entries/bodily-awareness/>. Último acesso: 21/04/2015.

FERRAZ, Marcus Sacrini Ayres. O transcendental e o existente em Merleau-Ponty. São Paulo: Associação Editorial Humanitas: FAPESP, 2006.

JASPERS, Karl. Psicopatologia Geral. Primeiro Volume. Tradução de Dr. Samuel Penna Aarão Reis. Rio de Janeiro: Atheneu, 1973.

MAZZÙ, Antonino. Syntaxe motrice et stylistique corporelle: réflexions à proposduschematismecorporelchexle premier Merleau-Ponty, Revue Philosophique de Louvain, Tomo 99. № 1, 2001, p. 46-72.

MERLEAU-PONTY, Maurice. Fenomenologia da Percepção. São Paulo: Martins Fontes, 2011.

. A ciência e a experiência da expressão. In: A prosa do mundo. São Paulo: Cosac Naify, 2012. (Cosac Naify Portátil).

O Olho e o Espírito. São Paulo: Cosac Naify, 2013. (Cosac Naify Portátil).

REYNOLDS, Jack. Existencialismo. Rio de Janeiro: Vozes, 2013. 